Scientific Journal Warsaw University of Life Sciences - SGGW

Problems of World Agriculture volume 17 (XXXII), number 4, 2017: 31-40

DOI: $10.22630 /$ PRS.2017.17.4.79

\title{
Ewa Cieślik
}

Poznan University of Economics and Business

\section{The New Silk Road: Seeking Opportunities for Polish Exports in the Chinese Market}

\begin{abstract}
The paper presents preliminary studies related to the problems of the New Silk Road and its influence on the Polish economy. The aim of the report is to define tendencies in the trade exchange between Poland and China and to evaluate the capacity of Polish exports to the Chinese market. The paper tries to answer the question whether the contemporary structure of Polish exports to the Chinese market allows for the full use of the potential of the Middle Kingdom market. In the study, the indicative trade potential was used.
\end{abstract}

Key words: China, Poland, economic relations, New Silk Road

JEL Classification: F14, F17

\section{Introduction}

When the Chinese President announced during his visits to Kazakhstan and Indonesia in October 2013 that he was going to reactivate the Silk Road, the initiative was not expected to unite so many countries. The New Silk Road, also known as One Belt One Road (OBOR) has become China's flagship international project for the coming years and the strategy largely affecting economic relations worldwide ${ }^{2}$. Poland has also become an element of this strategy, among others, due to its strategic geographical position. Analysing the current international situation and a growing role of China in the world economy ${ }^{3}$, Poland should not only avoid becoming closed to cooperation with this country, it should also strengthen cooperation in many dimensions.

Consequently, analysis of the current trade relations between Poland and China seems to be an important issue in terms of further cooperation and development of Poland's position in the OBOR. In the assessment of potential directions for cooperation, sectors of the Chinese economy which remain particularly attractive for Polish exporters are indicated.

The paper presents preliminary studies related to the issues of the New Silk Road. The aim of the report is to define tendencies in the trade exchange between Poland and China and to evaluate the capacity of Polish exports to the Chinese market. In this way, the paper tries to answer the question whether the current structure of Polish exports to the Chinese

\footnotetext{
${ }^{1}$ Ph.D., Al. Niepodległości 10, 61-875 Poznań, e-mail: ewa.cieslik@ue.poznan.pl.

The article is the result of the research project "Chinese New Silk Road strategy: implications for production linkages between China and Central and Eastern Europe" financed by the National Science Centre, Poland (UMO-2016/23/D/HS4/02748).

${ }^{2}$ In recent months, interesting reports on a possible role of the New Silk Road in the world in various areas, such as in the economic, security and political arenas, were published, inter alia, by Ghiasy and Zhou (2017), Saalman and Dethlefsen (2017), Blanchard and Flint (2017), Abdenur (2016), Putten et al. (2016), or Kaczmarski (2016).

${ }^{3}$ More on the role of China in the world economy, in the report by (Cieślik, 2012, 2015 and 2016).
} 
market allows for the full use of the potential of the Middle Kingdom market. Estimation of the potential exports was performed with the use of the indicative trade potential (ITP).

The paper is divided into five parts, including the introduction and the summary. The second section comprises a short presentation of the OBOR and Poland's role in the strategy. The third part of the paper presents the most important facts related to the PolishChinese trade exchange. The fourth part is an attempt to evaluate the capacity for the development of Polish exports to the Chinese market.

The subject of the study carried out in the paper comprises two countries: Poland and China. In the paper, 2016 was adopted as a research period (last available data in the scope of Polish trade with China). However, in justified cases (information on the Polish-Chinese trade exchange), the scope of the study was extended by adding earlier years. In order to standardise the results of the study, statistical data derived from the United Nations Conference on Trade and Development (UNCTAD) databases (mostly from the section: International trade in goods and services on UNCTAD Stat) were relied on.

\section{New Silk Road: Role of Poland in the Strategy}

The New Silk Road is the third stage of China's opening to the world (preceded by the creation of special economic zones in the 1980s and accession to the WTO in 2001). The initiative comprises 65 countries, including Poland, i.e. the total of almost 4.4 billion people (63\% of the world population). GDP of countries included in the OBOR is estimated at a level of approximately $30 \%$ of the global GDP. Until May 2017, over 40 countries and international organisations signed agreements concerning the OBOR creation with China. By the end of 2016, 8158 contracts between Chinese enterprises and foreign entities were signed within the framework of the OBOR. Under the strategy, six cooperation corridors shall be established: China-Pakistan, so-called New Eurasia Land Bridge, China-MongoliaRussia, China-Central Asia-Western Asia, China-Indochina Peninsula, Bangladesh-ChinaIndia-Myanmar. In 2016, the trade exchange between China and countries covered under the OBOR strategy amounted to USD 953 million, i.e. $25.7 \%$ of China's total trade volume (UNCTAD 2017).

In accordance with the OBOR assumptions, Poland is an important element of the project. In one of the options, the country appeared at the entry of land transport routes to Europe $^{4}$. By mid-2017, a number of events associated with the OBOR strategy in which Poland participated took place. In 2015, the President of the Republic of Poland paid a visit to China, during which strengthening of the economic cooperation between both countries was discussed. On the other hand, Xi Jinping, the President of the People's Republic of China paid a visit to Poland on 19-21 June 2016, which was the first visit to Poland at such a high level in 12 years. Subsequently, the Prime Minister of Poland participated in the One Belt One Road Forum in Beijing in May 20175. Poland is a member of the Asian Infrastructure Investment Bank. Minor events focusing around the OBOR also took place.

\footnotetext{
${ }^{4}$ The first option of the OBOR comprises the transport route running across Poland to Germany and further on, to other countries of Western Europe. The second option assumes entering Europe via Slovakia towards Vienna. The third option is the OBOR entering Europe via Bulgaria towards the North (Kaczmarski, 2015).

${ }^{5}$ Representatives of over 130 countries and 70 international organisations participated in the event (among others, the UN Secretary-General).
} 
On 20 May 2016, the 5th Europe-China Economic Cooperation Forum was held during the European Economic Congress in Katowice. At the end of April 2017, the first Research Centre of the New Silk Road of this type in Poland was established at the Poznań University of Technology, financed to a large extent by the Chinese party. Earlier, in October 2016, the Poznań University of Economics and Business initiated a research consortium between China and selected universities of Central and Eastern Europe, the "16+1 High Level Academic Platform". Up to date, many conferences and forums were also held, focusing on the New Silk Road as the leading subject, such as the launch of a railway connection between Chengdu and Łódź in 2013.

\section{Polish-Chinese Trade Exchange in 2016: General Information}

For Poland, China is the biggest trade partner in Asia. However, imports significantly exceed exports. In 2016, goods and services worth EUR 19.7 billion were imported to Poland whereas goods and services for EUR 1.5 billion were exported. This gave China $12.08 \%$ share in Polish imports and only $0.92 \%$ - in exports. Compared to the exchange carried out a decade ago, both Polish exports to China and imports from China have almost doubled. For years, Poland has been generating a high negative trade balance with China, which amounted to EUR 18.2 billion in 2016. The negative current account balance is the lowest for the exchange with China (UNCTAD 2017).

The average annual performance of exports in 2007-2016 reached a level over $8 \%$. However, this performance showed many fluctuations - there were years of very high growth, e.g. 2013 with a $21 \%$ growth in Polish exports to China and years of declines in exports rate, e.g. 2015 with a decline exceeding $10 \%$. In the case of imports, the average annual growth rate in 2007-2016 amounted to $13 \%$ and demonstrated less volatility than the performance of exports. In the last decade, years of very high growths of imports from China occurred (e.g. 2007 and 2008 with a growth amounting to $52 \%$ and $43 \%$, respectively) as well as years of sudden declines in the value of goods imported to Poland from China (e.g. 2009 showed a decline of as much as 17\%) (UNCTAD 2017).

Copper with the share of $19.8 \%$, furniture \& parts $(7.4 \%)$ and parts \& accessories of vehicles $(4.1 \%)$ remained the most important product groups exported from Poland to China in 2016. Compared to the preceding decade, the structure of exports became more advanced, although also at that time copper prevailed (29.8\%), followed by organoinorganic, heterocyclic compounds (12.5\%). In 2016, Poland imported mainly telecommunication equipment $(17.4 \%)$, automatic data processing machines $(8.3 \%)$ and parts \& accessories for automatic data processing machines and office equipment $(4.4 \%)$ from China. The structure of Polish imports from China has remained almost unchanged for a decade. Throughout all this period, telecommunication equipment and automatic data processing machines prevailed, although with various share in total imports (UNCTAD 2017). 


\section{Data, Methods and Results of the Study}

The evaluation of the Polish export potential in the trade in goods with China was performed based on indicative trade potential which was calculated according to the formula:

$$
\mathrm{ITP}=\min (\mathrm{XPi}, \mathrm{MAi})-\mathrm{XPAi}
$$

where:

$\mathrm{XP}$ - total Polish exports,

$\mathrm{MA}$ - total Chinese imports,

XPA - exports of Poland to China's market,

$\mathrm{i}$ - products/group of products

According to Mukherji (2007), "By matching the import demand with the export supply of a given commodity, an estimate can be made of the possibility of trade expansion under the most favourable competitive conditions, after subtracting existing trade". The trade potential index first was used by Mukherji (2003 and 2005) under the name "bilateral potential trade" to estimate the benefits of the negative list approach in the economic integration of the Asia-Pacific region. The index was also proposed by Helmers and Pasteels (2006) to estimate the trade potential at the commodity level. They argued that the ITP can avoid problems such as lack of data when using the gravity model. Further, because this index is based on a strong assumption of complementarity between two trade partners, it is an indicator of potential trade. Pant and Panta (2009) also used this method to estimate the trade potential between Nepal and the US. They identified the main trade potential of Nepal with the United States as being in wool carpet, fine animal hair, and cotton; whereupon they suggested that the Nepal government should diversify its exports. The trade potential measure has also been used by Paswan (2003) to identify trade potential in India's agriculture sector.

Data derived from UNCTAD databases were used in the analysis. Within the study, an attempt was undertaken aimed at verifying a hypothesis that Poland develops the structure of its exports to the Chinese market using the potential of the target market as well as its own exports capacity.

In accordance with the results obtained (Table 1), the potential exports to China are estimated at a level of over USD 194.5 billion, which already allows for the assumption that the structure of Polish exports to the Chinese market most probably does not follow Polish export capacity and the absorption capacity of the Middle Kingdom market. The current export activity of Poland to China is insignificant. In fact, in 2016, Poland used only $1 \%$ of its export capacity to China. This confirms, on the one hand, huge development opportunities for Polish goods exports to the Chinese market, but it simultaneously shows very neglected exports to China.

In absolute terms, the highest development potential of exports from Poland to China, calculated with the use of the ITP measure may be observed in the case of group parts \& accessories of vehicles [784], where the export capacity exceeded USD 11.2 billion, motor vehicles for the transport of persons [781]: USD 7.6 billion and articles of plastics [893]: USD 2.1 billion (Table 1). Among the listed product groups, group parts \& accessories of vehicles [784] (4.1\%) had the highest share in the structure of Polish exports to the Middle 
Kingdom. On the other hand, the remaining listed product groups demonstrated minor shares in Polish exports, amounting to $0.1 \%$ for motor vehicles for the transport of persons [781] and 1.6\% for articles of plastics [893] (UNCTAD 2017).

Among product groups included in Table 1, we use the capacity of the following product groups to the largest extent: copper [682] - 19.2\%, furniture \& parts [821] with the share of $5.2 \%$ occupies the second position and engines \& motors, non-electric; parts [714] with the share of $3.1 \%$ occupies the third place. The foregoing figures indicate that those product groups should be ranked at the top of the structure of Polish exports to the Middle Kingdom. That is really the case as in 2016, group copper [682] had a $19.8 \%$ share in the total Polish exports to China and it was the biggest product group reaching that market; on the other hand, furniture \& parts [821] constituted 7.4\% (vice-leader in the structure of Polish exports to China), whereas the share of engines \& motors, non-electric; parts [714] amounted to $3.3 \%$, which gave the group fifth place in the structure of exports to China. Taking into account all product groups in the SITC Rev3 classification, the highest share of actual exports in the potential exports was observed in 2016 in the case of the following product groups: copper ores and concentrates; copper mattes, cement [283] and it amounted to $39.7 \%$, group waste, parings and scrap, of plastics [579] and it amounted to $28.9 \%$ as well as group radio-actives and associated materials [525] and it amounted to $24.7 \%$. However, none of the product groups had a significant share in the structure of Polish exports to China $(0.17 \%-1.32 \%)$.

The analysis explicitly shows that Polish exports to the Chinese market are far from using the full potential. Product groups demonstrating the highest ITP values are ranked in further positions in the structure of Polish exports. Their share in the overall structure of Polish exports to China is often marginal, e.g. a group of vehicles for personal transport or plastic articles. Moreover, major product groups constituting Poland's exports to China still have the opportunity to increase their share in the absorptive market of the Middle Kingdom. The majority of top ten potential exports destinations of Table 1 indicated in the study, demonstrate a higher level of sophistication (stage of processing and technological intensity) than the current structure of exports. It is an important guidance in terms of the development and reconstruction of Polish exports to the Chinese market. 
Table 1. Indicative trade potential and actual trade of Poland with China in 2016 (millions of dollars and per cent)

\begin{tabular}{|c|c|c|c|c|c|c|c|c|}
\hline No. & Group of goods & $\mathrm{XP}_{\mathrm{i}}$ & $\mathrm{MA}_{\mathrm{i}}$ & $\mathrm{XPA}_{\mathrm{i}}$ & $\begin{array}{c}\text { Min } \\
\left(\mathrm{XP}_{\mathrm{i}}, \mathrm{MA}_{\mathrm{i}}\right)\end{array}$ & ITP & XPAi/ITPi. & $\begin{array}{c}\text { Actual } \\
\text { exports' } \\
\text { share }\end{array}$ \\
\hline & Total & 196455.3 & 1589420.4 & 1911.1 & 196455.3 & 194544.1 & $1.0 \%$ & - \\
\hline 1 & [784] Parts \& accessories of vehicles & 11314.7 & 27056.5 & 79.0 & 11314.7 & 11235.7 & $0.7 \%$ & $4.1 \%$ \\
\hline 2 & $\begin{array}{l}\text { [781] Motor vehicles for the transport } \\
\text { of persons }\end{array}$ & 7599.5 & 52971.7 & 2.1 & 7599.5 & 7597.4 & $0.0 \%$ & $0.1 \%$ \\
\hline 3 & [893] Articles of plastics & 4378.7 & 4483.8 & 30.8 & 4378.7 & 4347.9 & $0.7 \%$ & $1.6 \%$ \\
\hline 4 & $\begin{array}{l}\text { [713] Internal combustion piston } \\
\text { engines, parts }\end{array}$ & 4179.8 & 9929.4 & 8.3 & 4179.8 & 4171.6 & $0.2 \%$ & $0.4 \%$ \\
\hline 5 & $\begin{array}{l}\text { [752] Automatic data processing } \\
\text { machines }\end{array}$ & 3910.7 & 16949.5 & 31.5 & 3910.7 & 3879.2 & $0.8 \%$ & $1.6 \%$ \\
\hline 6 & [699] Manufactures of base metal & 3854.6 & 5167.3 & 25.7 & 3854.6 & 3828.9 & $0.7 \%$ & $1.3 \%$ \\
\hline 7 & $\begin{array}{l}\text { [764] Telecommunication equipment } \\
\& \text { parts }\end{array}$ & 3369.6 & 32886.8 & 50.4 & 3369.6 & 3319.2 & $1.5 \%$ & $2.6 \%$ \\
\hline 8 & $\begin{array}{l}\text { [778] Electrical machinery \& } \\
\text { apparatus }\end{array}$ & 3314.8 & 21177.0 & 65.4 & 3314.8 & 3249.5 & $2.0 \%$ & $3.4 \%$ \\
\hline 9 & [012] Other meat and edible meat offal & 2897.7 & 4833.6 & 33.0 & 2897.7 & 2864.8 & $1.2 \%$ & $1.7 \%$ \\
\hline 10 & $\begin{array}{l}\text { [553] Perfumery, cosmetics or toilet } \\
\text { prepar. (excluding soaps) }\end{array}$ & 2899.0 & 2749.5 & 6.1 & 2749.5 & 2743.4 & $0.2 \%$ & $0.3 \%$ \\
\hline 11 & [821] Furniture \& parts & 10500.5 & 2801.0 & 141.8 & 2801.0 & 2659.2 & $5.3 \%$ & $7.4 \%$ \\
\hline 12 & $\begin{array}{l}\text { [773] Equipment for distributing } \\
\text { electricity }\end{array}$ & 2670.5 & 5444.1 & 44.9 & 2670.5 & 2625.5 & $1.7 \%$ & $2.4 \%$ \\
\hline 13 & $\begin{array}{l}\text { [772] Apparatus for electrical circuits; } \\
\text { board, panels }\end{array}$ & 2539.4 & 32624.7 & 63.0 & 2539.4 & 2476.5 & $2.5 \%$ & $3.3 \%$ \\
\hline 14 & $\begin{array}{l}\text { [542] Medicaments (incl. veterinary } \\
\text { medicaments) }\end{array}$ & 2472.0 & 15095.8 & 19.7 & 2472.0 & 2452.3 & $0.8 \%$ & $1.0 \%$ \\
\hline 15 & [641] Paper and paperboard & 2242.7 & 3369.5 & 9.6 & 2242.7 & 2233.1 & $0.4 \%$ & $0.5 \%$ \\
\hline 16 & $\begin{array}{l}\text { [334] Petroleum oils or bituminous } \\
\text { minerals }>70 \% \text { oil }\end{array}$ & 2209.3 & 14558.8 & 9.3 & 2209.3 & 2200.0 & $0.4 \%$ & $0.5 \%$ \\
\hline 17 & $\begin{array}{l}\text { [714] Engines \& motors, non-electric; } \\
\text { parts }\end{array}$ & 2127.0 & 5166.7 & 63.0 & 2127.0 & 2064.1 & $3.1 \%$ & $3.3 \%$ \\
\hline 18 & [682] Copper & 2353.3 & 28066.7 & 379.2 & 2353.3 & 1974.1 & $19.2 \%$ & $19.8 \%$ \\
\hline 19 & $\begin{array}{l}\text { [598] Miscellaneous chemical } \\
\text { products }\end{array}$ & 1871.9 & 12541.5 & 14.7 & 1871.9 & 1857.2 & $0.8 \%$ & $0.8 \%$ \\
\hline 20 & $\begin{array}{l}\text { [743] Pumps (excluding liquid), gas } \\
\text { compressors \& fans; centr. }\end{array}$ & 1814.9 & 10771.01 & 13.8 & 1814.9 & 1801.1 & $0.8 \%$ & $0.7 \%$ \\
\hline
\end{tabular}

Top 20 groups of goods with the highest ITP. The number of merchandise classification group in SITC Rev3 Product is in brackets.

Source: (UNCTAD 2017), Author's own calculations. 
The potential exports of Poland to China are also worth analysing according to the level of processing and technological intensity of products. Data contained in Table 2 illustrate a low technological advancement of Polish exports. In all categories, the actual exports cover a minor part of the potential exports.

Table 2. Indicative trade potential and actual trade of Poland with China in terms of technological intensity, 2016 (millions of dollars and per cent)

\begin{tabular}{|c|c|c|c|c|c|c|c|}
\hline Group of goods & $X P_{i}$ & $\mathrm{MA}_{\mathrm{i}}$ & $\mathrm{XPA}_{\mathrm{i}}$ & $\begin{array}{c}\text { Min } \\
\left(\mathrm{XP}_{\mathrm{i}}, \mathrm{MA}_{\mathrm{i}}\right)\end{array}$ & ITP & XPAi/ITPi. & $\begin{array}{l}\text { Actual } \\
\text { exports' } \\
\text { share }\end{array}$ \\
\hline Primary products & 17507.3 & 306347.1 & 462.6 & 17507.3 & 17044.8 & $2.71 \%$ & $24.2 \%$ \\
\hline $\begin{array}{l}\text { Resource-based } \\
\text { manufactures: } \\
\text { agro-based }\end{array}$ & 24921.1 & 80891.4 & 170.3 & 24921.1 & 24750.7 & $0.69 \%$ & $8.9 \%$ \\
\hline $\begin{array}{l}\text { Resource-based } \\
\text { manufactures: } \\
\text { other }\end{array}$ & 9750.4 & 230234.1 & 146.3 & 9750.4 & 9604.1 & $1.52 \%$ & $7.7 \%$ \\
\hline $\begin{array}{l}\text { Low technology } \\
\text { manufactures: } \\
\text { textile, garment } \\
\text { and footwear }\end{array}$ & 9139.4 & 32896.5 & 25.8 & 9139.4 & 9113.6 & $0.28 \%$ & $1.4 \%$ \\
\hline $\begin{array}{l}\text { Low technology } \\
\text { manufactures: } \\
\text { other products }\end{array}$ & 34151.5 & 48801.6 & 263.0 & 34151.5 & 33888.5 & $0.78 \%$ & $13.8 \%$ \\
\hline $\begin{array}{l}\text { Medium } \\
\text { technology } \\
\text { manufactures: } \\
\text { automotive }\end{array}$ & 22844.1 & 82012.2 & 84.6 & 22844.1 & 22759.6 & $0.37 \%$ & $4.4 \%$ \\
\hline $\begin{array}{l}\text { Medium } \\
\text { technology } \\
\text { manufactures: } \\
\text { process }\end{array}$ & 16173.3 & 124182.7 & 73.6 & 16173.3 & 16099.7 & $0.46 \%$ & $3.9 \%$ \\
\hline $\begin{array}{l}\text { Medium } \\
\text { technology } \\
\text { manufactures: } \\
\text { engineering }\end{array}$ & 35263.4 & 199795.0 & 385.1 & 35263.4 & 34878.3 & $1.10 \%$ & $20.2 \%$ \\
\hline $\begin{array}{l}\text { High technology } \\
\text { manufactures: } \\
\text { electronic and } \\
\text { electrical }\end{array}$ & 18649.8 & 346665.5 & 220.5 & 18649.8 & 18429.3 & $1.20 \%$ & $11.5 \%$ \\
\hline $\begin{array}{l}\text { High technology } \\
\text { manufactures: } \\
\text { other }\end{array}$ & 5477.8 & 134333.7 & 73.9 & 5477.8 & 5403.9 & $1.37 \%$ & $3.9 \%$ \\
\hline $\begin{array}{l}\text { Unclassified } \\
\text { products }\end{array}$ & 2577.1 & 3260.5 & 5.4 & 2577.1 & 2571.7 & $0.21 \%$ & $0.3 \%$ \\
\hline
\end{tabular}

Products classification groups on the basic of Lall (2000).

Source: (UNCTAD 2017), Authors' own calculations.

The highest share is observed in the case of primary products $(2.71 \%)$. At the same time, primary products have the highest share in actual Polish exports to China (24.2\%). It 
turns out that the highest value of potential exports sent to China is observed in the case of products classified in the "medium technology manufactures: engineering" class (almost 34.8 billion). In 2016, this group of goods accounted for $20.2 \%$ of Polish exports to China. A slightly lower exports potential is observed in the goods category "low technology manufactures: other products" (USD 33.9 billion). Resource-based manufactures: agrobased occupy the third position (almost USD 24.8 billion). For those three product types, the largest market niche for Polish exports appears. However, for the purpose of highlighting the Polish presence in the Chinese market, the increase in the exports of more technologically advanced goods would be more important. The actual value of exports of this product category in 2016 amounted to $15.4 \%$ of the total exports to the Middle Kingdom. Polish exports of high technology goods cover slightly over $2.5 \%$ of potential exports that could be directed to the Chinese market. Overall, the ITP for all types of high technology products in 2016 amounted to over USD 23.8 billion, including: USD 18.4 billion for the "high technology manufactures: electronic and electrical" subcategory and USD 5.4 billion for "high technology manufactures: other". Both subcategories of goods covered $1.2 \%$ and $1.37 \%$, respectively, of the potential exports to the Middle Kingdom. In general, the share of exports categorised as the highest technology for Poland is still too low for a highly developed country 6 .

\section{Summary}

Polish exports to the Chinese market demonstrate a low level of sophistication and they are insignificant as compared to the size of imports. The New Silk Road offers the opportunity to Poland in the scope of catching-up exports arrears. The analysis presented in the paper has confirmed that Poland almost fails to use its export opportunities to the Chinese market ${ }^{7}$. Only in the case of less advanced products, Polish exports covered potential exports to a larger extent. The current commodity structure of Polish exports to the Middle Kingdom places our country among insignificant suppliers and the high value of goods imported from China to Poland shows a considerable asymmetry in mutual trade relations. In addition, the negative trade balance with China continuing for years and a limited restructuring of the structure of goods exported to this market, indicate very neglected exports and treating the Chinese market as an occasional purchaser of our goods rather than a permanent partner towards which a long-term export strategy should be developed.

Obviously, one should be aware of the limitations of the method applied in the study.

First of all, the analysis conducted is of an ex post nature, i.e. it does not take into account future changes in the conditions of development of trade exchange between Poland and China. A certain probability exists that as a result of the implemented OBOR strategy and efforts of the authorities (especially the Polish party), exports to the Chinese market will intensify in the coming years.

\footnotetext{
${ }^{6}$ In 2016, the share of such exports reached only $12.3 \%$, whereas the share of high technology directed to China in exports amounted to $15.4 \%$ in 2016. Primary products have the highest share in Polish exports to the Middle Kingdom (approximately one-fourth of exports) (UNCTAD 2017).

${ }^{7}$ The aversion of the Polish exporter to the Chinese market partly arises from numerous trade barriers faced by it in China.
} 
Secondly, the construction of the indicative trade potential applied is based on the assumption that Poland's exports in the scope of specific goods may be assigned for covering the Chinese demand for imported goods and the presented values of Poland's potential exports to the Middle Kingdom are only indicative. Therefore, the results obtained may be treated as specific guidelines concerning the future directions of Polish exports to the Chinese market.

Thirdly, alternative methods of calculating the potential trade value exist. Methods adopted in the studies of Kabir and Salim (2011), Pastore et al. (2009), or Salim et al. (2011) may serve as an example of a different approach. The afore-mentioned alternative methods may be used in the future to supplement the analysis conducted.

Notwithstanding the limitations of the method applied, the analysis has demonstrated that the structure of Polish exports to the Chinese market in 2016 did not allow for the full use of the capacity. Polish exporters practically neglected the most prospective groups of goods for which demand exists in the Chinese market. Moreover, Polish exports concentrate on product groups which are less prospective, i.e. those with a lower value of potential exports.

Using the opportunities resulting from the accession to the OBOR by Poland depends, to a large extent on the construction of a coherent strategy and vision related to Poland's role in the project. Summit meetings or minor initiatives associated with the OBOR must be supported by specific measures aimed at strengthening the cooperation. Any such events should be concluded by signing contracts or negotiating more favourable conditions for Polish businesses operating in China.

\section{Literature}

Abendur, A.E. (2016). The Geopolitics of East Asia: New Geometries of Competition and Cooperation. CEBRI Report.

Blanchard, J.M.F., Flint, C. (2017). The Geopolitics of China's Maritime Silk Road Initiative. Geopolitics, 22(2), 223-245.

Cieślik, E. (2012). Efekt smoka. Skutki ekspansji gospodarczej Chin po 1978 roku. Wydawnictwa Fachowe CeDeWu. Warszawa.

Cieślik, E. (2015). Rozwój gospodarczy Chin od roku 1978 do kryzysu globalnego. Wydawnictw Key Text. Warszawa.

Cieślik, E. (2016). Potencjał ekonomiczny Chin i jego pozycja w gospodarce światowej. Przeglad Zachodni, 4(361), 99-116.

Ghiasy, R., Zhou, J. (2017). The Silk Road Economic Belt. Considering Security Implications and EU-China Cooperation Porspects. SIPRI.

Helmers, C., Pasteels, J. (2006). Assessing the Bilateral Trade Potential at the Commodity Level: An Operational Approach. ITC Working Paper, November.

Kabir, S., Salim, R.A. (2011). Parallel integration and ASEAN-EU trade potential: An empirical analysis. Journal of Economic Integration, 26(4), 601-623.

Kaczmarski, M. (2015). Nowy Jedwabny Szlak: uniwersalne narzędzie chińskiej polityki. Komentarze OSW, 161. Accessed from: https://www.osw.waw.pl/sites/default/files/komentarze_161_0.pdf.

Kaczmarski, M. (2016). Jedwabna globalizacja. Chińska wizja ładu międzynarodowego. Punkt Widzenia. Ośrodek Studiów Wschodnich, 60. Accessed from: https://www.osw.waw.pl/sites/default/files/pw 60 pl jedwabna globalizacja_net.pdf.

Lall, S. (2000). The Technological Structure and Performance of Developing Country Manufactured Exports, 1985-1998, QEH Working Paper Series, nr 44.

Mukherji, I.N. (2003). The Bangkok agreement: A negative list approach to trade liberalisation in Asia and the Pacific Standing Committee of the Bangkok Agreement, Bangkok, 19-21 March 2003. 
Mukherji, I.N. (2005). The Bangkok agreement: A negative list approach to trade liberalisation in Asia and the Pacific. Asia-Pacific Trade and Investment Review, 1(2), 27-53.

Mukherji, I.N. (2007). Asia-Pacific trade agreement: Implications of exchange of trade preferences for member and prospective member countries (Research Document). UNESCAP.

Pant, B., Panta, R.K. (2009). Export diversification and Competitiveness: Nepal's Experience. Economic Review: Occasional Paper, 21, 52-78.

Pastore, F., Ferragina, A. M., Giovannetti, G. (2009). A tale of parallel integration processes: A gravity analysis of EU trade with Mediterranean and central and eastern European countries. Review of Middle East Economics and Finance, 5(2), 21-44.

Paswan, N.K. (2003). Complementarity and trade potential in India's trade in agricultural food products Agricultural trade in South Asia: Potential and policy options (pp. 255-344). New Delhi, India: APH Publishing Corporation.

Putten, F.P., Seaman, J., Huotari, M., Ekman A., Otero-Iglesias M. (2016). Europe and China's New Silk Roads. Report by the European Think-tank Network on China (ETNC).

Saalman, L., Dethlefsen, K. (2017). Following the Forum. China's Belt and Road Initiative and the EU. Friedrich Ebert Stiftung.

Salim, R.A., Kabir, M.M., Al Mawali, N. (2011). Does More Trade Potential Remain in Arab States of the Gulf? Journal of Economic Integration, 26(2), 217-243.

UNCTAD (2017). UNCTAD Stats. Accessed 23 August 2017 from: http://unctad.org/en/Pages/Statistics.aspx. 